\title{
Design of Realistic Mathematics-Based Student Worksheets to Improve Students' Critical Thinking Ability
}

\author{
Suparman*, Dita Dwigus Wijayanti \\ Graduate School, Ahmad Dahlan University Yogyakarta, Indonesia \\ *Corresponding author: suparman@pmat.uad.ac.id
}

DOI: https://doi.org/10.37134/ajatel.vol9.no1.4.2019

Published: 15 June 2019

\begin{abstract}
Critical thinking ability is one of the abilities that must be possessed by students in the 2013 curriculum learning. Worksheets Students who have not integrated critical thinking skills will hinder learning objectives. The Indonesian Realistic Mathematics Approach is one approach that can be used by teachers to be able to improve students' critical thinking. This study aims to design worksheets of students who use the Indonesian Realistic Mathematics Approach to improve critical thinking skills and to produce the design of mathematics student worksheets with a realistic mathematical approach for students of class X Vocational High School. This research applied the ADDIE development model research, which consists of four stages: Analysis, Forming, Developing, Implementing and Evaluating. It focuses on the product planning stage of the students' worksheet. Two schools were involved in this study were YPKK 3 vocational school Sleman Yogyakarta and Budi Mulia 2 vocational school Yogyakarta. A questionnaire was administrated to the respondents of this study. The results showed that the material feasibility test with an average score of 89. Thus, the design of student worksheets with realistic mathematical approach is promising.
\end{abstract}

Keywords: design, student worksheets, realistic mathematics, critical thinking, learning

\section{INTRODUCTION}

In the current era of globalization, it is very easy for someone to get information, for example through print media, electronic media, books, or the internet (Selasih, 2018). So that information obtained by someone can be effective and does not cause a negative impact, a "filter" is needed to filter every information received. One of these filters is the critical thinking ability that a person has (Lövestam et al., 2018). With the ability to think critically someone will determine / consider carefully and deliberately whether to accept, reject, or delay receiving information (Ulya \& Retnoningsih, 2014).

Critical thinking is reasoned and reflective thinking by emphasizing making decisions about what to believe or do (Richland et al., 2018). Thus critical thinking considers and evaluates information which ultimately enables students to actively make decisions. Mathematical materials and critical thinking skills are two things that cannot be separated. Because mathematical material is understood through critical thinking. Whereas critical thinking is trained through learning mathematics (Nurhikmayati, 2018). A student is said to have the ability to think critically if they has a systematic way of thinking, awareness in thinking, and has the ability to distinguish a truth from error (Sumarmo et al., 2018).

However, this critical thinking habit has not been traditionalized in schools (Ramos, 2018). Few schools teach their students critical thinking. Schools actually encourage students to give correct answers rather than encourage them to come up with new ideas or rethink existing conclusions. The importance of developing critical thinking skills since elementary school, it is absolutely necessary for mathematics learning to involve students more actively in the learning process itself (Estapa et al., 2017). In this case the role of the teacher in teaching and learning activities is as a facilitator and motivator to optimize student learning. Teachers should not only provide finished knowledge, but students at least actively build knowledge in their own minds. 
Based on the results of the PISA study (the Program for International Student Assessment), a study developed by several developed countries in the world every three years is incorporated in the Organization for Economic Cooperation and Development (OECD) based in Paris (France), where The study carried out was to monitor the results of student learning outcomes in each participating country which included reading literacy (reading literacy), mathematical literacy (scientific literacy), and scientific literacy, indicating that the ranking of science achievements for Indonesia was ranked 60 out of 65 countries that participated in the PISA 2009 study, with details as follows: reading literacy was ranked 57, mathematical literacy was ranked 61, and scientific literacy was ranked 60 (Wijaya,2015).

To realize students have critical thinking skills, material needs to be presented in teaching materials in the form of Student Worksheets. The student worksheets should be focused on applications in daily life or linked to a world that is close to students (the Real world), the material presented is contextual problems by presenting at all levels of mathematics learning goals (Zulkardi, 2002). In developing teaching materials an appropriate approach / method is needed (Heuvelpanhuizen \& Drijvers, 2014).

The selection of the right method in learning mathematics is needed in helping students understand the material taught and is also expected to be able to improve critical thinking skills. But the problem that occurs now is that most teachers do not develop their own teaching materials but buy from book agents. The instructional materials from these agents were not adjusted to the conditions of the school and the condition of the students (Kuhn, 1999). Based on the description, the researcher was interested in developing a module with a realistic mathematical approach to improve students' critical thinking skills in the material of linear equations of two class $\mathrm{X}$ variables. The purpose of this study was to produce student worksheets designs with realistic mathematical approaches to improve critical thinking skills. This article consists of several parts. The first part describes the introduction. The second part describes the research method. The third part describes the results and discussion. The fourth part explains the conclusions and and implications.

\section{RESEARCH METHOD}

The ADDIE development model consists of 5 steps, namely: analysis, design, development, implementation and evaluation (Ripley, 2015). In this study limited only up to two stages, namely the analysis and design stages as illustrated in Figure 1. At the analysis stage, researchers conduct material analysis, curriculum analysis, student analysis, analysis of learning objectives. Then the design phase of the researcher designed the student worksheet that was developed. Furthermore, the development stage researchers conducted product validation and tested it at Vocational School in Yogyakarta. The instruments used were interview interviews and questionnaire guidelines. The data analysis technique used was analyzing each questionnaire item, both the material expert questionnaire, media expert, and student response measured.

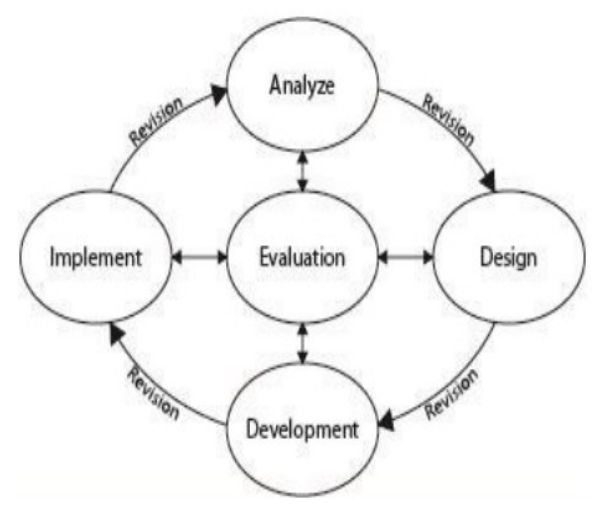

Figure 1. The main elements in the model system approach to instructional design and development (Branch, 2009) 


\section{DISCUSSION}

This study uses the ADDIE model (analysis, design, development, implementation and evaluation). The first stage is defined which aims to determine and analyze the conditions of learning. The stages in the definition include the initial analysis, student analysis, material analysis, task analysis, and the formulation of learning objectives.

In the initial analysis phase, the results obtained in the form of curriculum analysis of the sequence of mathematics subjects and series material for students of class X SMK that refers to the 2013 curriculum include identification of Core Competencies, Basic Competencies, subject matter, learning activities, assessment, time allocation, and learning resources used. The results of curriculum analysis are listed in the mathematics syllabus in the sequence and series sub-ject matter available in the 2013 curriculum. The basic competencies contained in the syllabus are translated into indicators of competency achievement.

This indicator is a reference for the construction of Student Worksheets. Syllabus are found in the order and material in Table 1.

Table 1. Basic competence

\begin{tabular}{|l|l|}
$\begin{array}{l}\text { 3.3. Determining the value } \\
\text { of the variable in the system } \\
\text { of linear equations are two } \\
\text { variables in the contextual } \\
\text { problem }\end{array}$ & $\begin{array}{l}\text { 4.3. Presenting the problem } \\
\text { solving system of two } \\
\text { variable linear equations }\end{array}$ \\
\hline
\end{tabular}

Table 1 shows 2 important basic competencies that will be used to design student worksheets. Observations and interviews with class X students showed that both students' confidence and critical thinking ability were low. Low student confidence is indicated by students' doubts in answering teacher questions. While students 'low critical thinking skills can be seen from students' answers when the teacher gives HOTS type questions. When given HOTS questions most students cannot answer correctly. So that students' confidence and critical thinking skills are still low.

After student analysis, task analysis is carried out. Task step analysis used to analyze tasks that must be mastered by students so that competencies can be achieved. The task is in the form of group assignments, individual assignments are used to measure students' abilities in sequence and series material. Formulation of learning objectives. The steps in formulating learning objectives are obtained results in the formulation of learning objectives from indicators of achievement of competencies that have been developed previously. The learning objectives are in Table 2.

Table 2. Learning objectives

\begin{tabular}{cl}
\hline No & \multicolumn{1}{c}{ Learning Objectives } \\
\hline 3.3 .1 & $\begin{array}{l}\text { With discussion students can understand the material of two-variable linear } \\
\text { equation systems carefully. }\end{array}$ \\
3.3 .2 & $\begin{array}{l}\text { With the help of student worksheets can determine the value of variables in a } \\
\text { system of linear two-variable equations correctly. }\end{array}$ \\
4.3.1 & $\begin{array}{l}\text { With discussion students can identify the system problems of two-variable linear } \\
\text { equations carefully }\end{array}$ \\
4.3.2 & $\begin{array}{l}\text { By taking turns the students come to the front of the class to present the results of } \\
\text { the completion of a two-variable linear equation system with responsibility }\end{array}$ \\
\hline
\end{tabular}

The second stage design, which aims to design student worksheets developed. The stages in the design include media selection, format selection, initial design. Based on task analysis, concept analysis, and facilities available at the school, the media chosen is student worksheets. The following view about the initial design of learning student worksheets based on realistic mathematics is guided in Figure 2. 

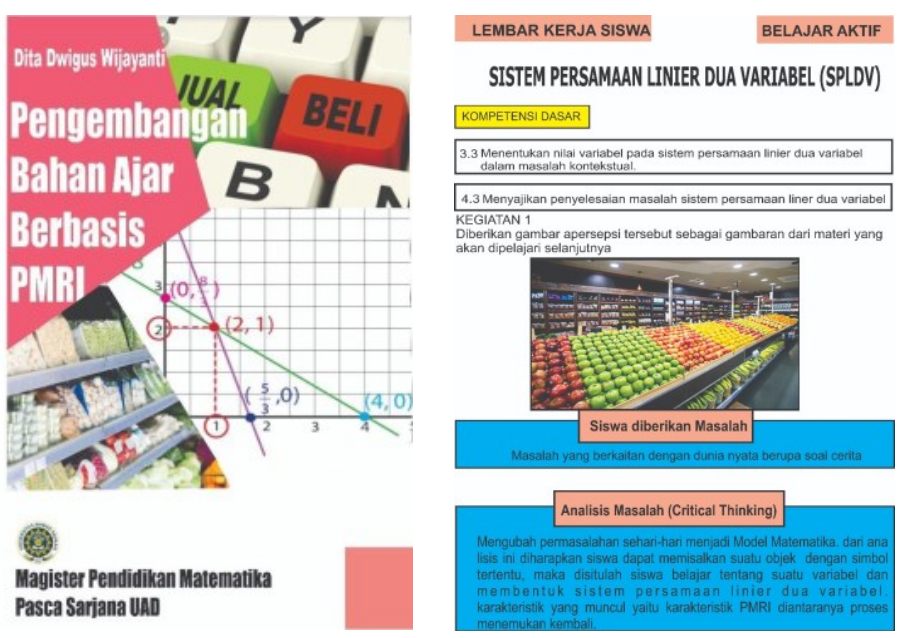

Figure 2. Student worksheets design

The formation of sequential learning media development includes the design of the contents of student worksheets presented including the design of student worksheets presented systematically, material that is in accordance with the basic competencies in the 2013 curriculum, the design of existing student worksheets in accordance with mathematical realistic characteristics, the activities presented can improve students' critical thinking and the presentation of designs on student worksheets with pictures and illustrations. The initial design referred to in this paper is the design of all activities carried out before the trial is carried out. The results of the initial draft of this student worksheet are draft I.

The third stage of development is the realization phase of student worksheets and instrument design used to measure the performance of products that have been developed. There is expert validation, media validation, and testing.

At the expert validation stage, the assessment was conducted to determine the validity of the design of the student worksheets developed. The design of student worksheets that have been approved by the supervisor is then validated by teachers from two different vocational schools. Validation of student worksheet designs using assessment instruments that have been reviewed by lecturers, while the instruments are in the form of questions and questionnaires. After a valid instrument can be used by material experts and media experts to assess the module being developed. The material experts collect from of two people, Mathematics Teacher at Vocational School, Yogyakarta.

Material experts in this matter do not revise the learning media. However, material experts corrected the material to be used in learning media. Following are some of the input and suggestions from the material experts summarized in Table 3.

Table 3. Input and design suggestions for student worksheets

\begin{tabular}{ll}
\hline Feedback and Suggestions & \multicolumn{1}{c}{ Follow-up } \\
\hline $\begin{array}{l}\text { Taking issues in problem } \\
\text { formulation is not right. Try } \\
\text { to find a more suitable } \\
\text { problem }\end{array}$ & Change some problems \\
$\begin{array}{ll}\text { Construction in the student } \\
\text { worksheet is more detailed }\end{array}$ & $\begin{array}{l}\text { Complete the student } \\
\text { worksheet }\end{array}$ \\
\hline
\end{tabular}

Input and advice from experts was then revised. Furthermore, the feasibility of learning material was assessed by three material experts. The following are the results of a questionnaire calculation about the feasibility of learning media by the material experts shown in Table 4. Based on Table 4, it can be seen that the average score of material experts is 89 . These results indicate that the learning media developed in terms of material are in a very good category. 
Table 4. Results of calculation of material feasibility questionnaire

\begin{tabular}{|c|c|c|c|}
\hline Asessor & Department & Score & $\begin{array}{c}\text { Criteria for } \\
\text { Quantitative } \\
\text { data }\end{array}$ \\
\hline $\begin{array}{l}\text { Firdiana } \\
\text { Rakhmawati, } \\
\text { S.Pd }\end{array}$ & $\begin{array}{l}\text { Mathematics } \\
\text { teacher at } \\
\text { YPKK } 3 \\
\text { vocational } \\
\text { school in } \\
\text { Yogyakarta }\end{array}$ & 88 & Very good \\
\hline $\begin{array}{l}\text { Ika Septiana, } \\
\text { S.Pd }\end{array}$ & $\begin{array}{l}\text { Mathematics } \\
\text { teacher at } \\
\text { Budi Mulia } \\
2 \text { vocational } \\
\text { school in } \\
\text { Yogyakarta }\end{array}$ & 90 & Very good \\
\hline Total & & 178 & \\
\hline Rata-Rata & & 89 & Very good \\
\hline
\end{tabular}

\section{CONCLUSION}

This research is development research using the ADDIE method which is limited to the design stage. The design of the student worksheets was developed based on the realistic characteristics of mathematics in the Two Variable Linear Projection System which has characteristics using real world contexts, construction, mathematization processes, interactivity and integrated learning. The design of student worksheets developed based on Realistic Mathematics Education to improve students' critical thinking after being validated by material experts obtained an 89 score with a very good category.

\section{REFERENCES}

Branch, R.M. (2009). Instructional design: The ADDIE approach. Switzerland: Springer Science \& Business Media.

Estapa, A., Hutchison, A., \& Nadolny, L. (2017). Recommendations to support computational thinking in the elementary classroom. Technology and Engineering Teacher, 77(4), 25-29.

Kuhn, D. 1999. A developmental model of critical thinking. Educational Researcher, 28(2), 16-46.

Lövestam, E., Vivanti, A., Steiber, A., Boström, A.M., Devine, A., Haughey, O., \& O’Sullivan, T.A. (2018). The International Nutrition Care Process and Terminology Implementation Survey: Towards a Global Evaluation Tool to Assess Individual Prac-titioner Implementation in Multiple Coun-tries and Languages. Journal of the Academy of Nutrition and Dietetics, 119(2), 242-260.

Nurhikmayati, I. (2018). Scientific Learning to Improve Critical Thinking Ability. Eduma: Mathematics Education Learning and Teaching, 7(2), 1-10.

Ramos, J.J.R. (2018). Critical Thinking Skills Among Senior High School Students and its Effect in Their Academic Performance. International Journal of Social Sciences \& Humanities, 3(2), 61-73.

Richland, L.E., Begolli, K.N., \& Näslund-Hadley, E. Development of Mathematical Thinking.

Ripley, D. (2015). An Examination of Flipped Instructional Method on Sixth Graders' Mathematics Learning: Utilizing Propen-sity Score Matching (Doctoral disserta-tion).

Selasih, N. N., Sudarsana, I. K., Puspa, I. A. T., Ananda, I. N., Dwitayasa, I. M., Oktarina, N. P. S., \& Suhardiana, I. P. A. (2018, November). The Position Of Hindu Wom-en In Information Technology Era As A Strategic Issues And Epistemological Equivalents of Cultural Studies. In Journal of Physics: Conference Series (Vol. 1114, No. 1, p. 012084). IOP Publishing.

Sumarmo, U., Kusnadi, A., \& Maya, R. (2018). Mathematical Critical Think-Ing Ability And Disposition (Experiment with Vocational High School Students Using Scientific Approach). Journal of Educational Experts, 1(2). 
Ulya, H.K., \& Retnoningsih, A. (2014). Analysis of Mathematics Problem Solving Ability of Junior High School Students Viewed from Students Cognitive Style. Int. J.Educ. Res., 2(10), 577-582.

Heuvel-panhuizen, M.V.D., \& Drijvers, P. (2014). Realistic mathematics education. Encyclopedia of Mathematics Education, 521-525. https://doi.org/10.1007/978-94-007-4978-8

Wijaya, A. (2015). Context-based mathematics tasks in Indonesia: Toward better practice and achievement. Utrecht University.

Zulkardi, Z. (2002). Developing a learning envi-ronment on realistic mathematics educa-tion for Indonesian student teachers (Doc-toral dissertation, University of Twente, Enschede). 